\title{
Spawning Period and Size at Maturity of Scaldback, Arnoglossus kessleri Schmidt, 1915 (Pleuronectiformes: Bothidae), Caught by Beam Trawl in The Black Sea, Turkey
}

\author{
Sabri Bilgin ${ }^{1}\left(\mathbb{D}\right.$, Hatice Onay ${ }^{2}$ (D)
}

Cite this article as: Bilgin, S., Onay, H. (2020). Spawning period and size at maturity of scaldback, Arnoglossus kessleri Schmidt, 1915 (Pleuronectiformes: Bothidae), caught by beam trawl in the Black Sea, Turkey. Aquatic Sciences and Engineering, 35(1), 13-18.

ORCID IDs of the authors: S.B. 0000-0003-0155-8981; H.O. $0000-0003-3463-7360$

${ }^{1}$ Sinop University, Faculty of Fisheries, Sinop - TR57000, Turkey ${ }^{2}$ Recep Tayyip Erdoğan University, Faculty of Fisheries, Rize TR53000, Turkey

Submitted: 03.09.2019

Revision Requested:

24.10.2019

Last Revision Received:

24.10.2019

Accepted:

05.11.2019

Online published:

28.11.2019

Correspondence:

Sabri Bilgin

E-mail:

sbrbilgin@hotmail.com

(C) Copyright 2020 by Aquatic

Sciences and Engineering

Available online at

https://dergipark.org.tr/ase

\section{ABSTRACT}

The scaldback, Arnoglossus kessleri, is a small fish that belongs to the Bothidae family. This species is a demersal fish inhabiting sandy and muddy bottoms where it lives, generally buried in the sand. Even in Turkey, the biology of $A$. kessleri is unknown, and there are very few complete studies of the biology of this fish in the Mediterranean Sea, including the Aegean Sea and the Sea of Marmara. To describe the spawning period, size at maturity $\left(L_{m}\right)$, and length at maximum yield per recruit $\left(L_{\text {opt }}\right)$ of $A$. kessleri, and to assess the differences in these parameters from other populations, a total of 12 months samplings were conducted between December 2012 and November 2013 in the Black Sea. The monthly fluctuation of the GSI values showed that the spawning period was between June and September in the study area. The $L_{m}$ was estimated as $5.76 \mathrm{~cm}$ for females and $6.03 \mathrm{~cm}$ for males. The $L_{\text {opt }}$ was calculated from the empirical relationships between the $L_{\text {opt }}$ and $L_{m^{\prime}}$ and it was determined as smaller than $L_{m}$ for both sexes $\left(L_{\text {opt }}=5.55 \mathrm{~cm}\right.$ for female and $L_{\text {opt }}$ $=5.82 \mathrm{~cm}$ for male) and also the reproductive load, $L_{m} / L_{\max }$ of females was estimated as a bit (1.4\%) larger than males. The results of this study were offered as biological input parameters regarded as a reference for the management of the Black Sea stocks of the scaldback species.

Keywords: Scaldback, Arnoglossus kessleri, spawning period, size at maturity, fisheries management, Black Sea

\section{INTRODUCTION}

The Bothidae family of sinistral flatfishes (lefteye flounder) contains about 20 genera and 164 species (Froese \& Pauly, 2019), and many bothid genera have wide geographic distributions with representative species widely distributed throughout temperate and tropical seas (Gibson, Nash, Geffen, \& van der Veer, 2015). Arnoglossus is a speciose genus with members distributed from off the Atlantic coast of Europe and Africa, in the Mediterranean and Black seas, throughout the Indo-West and South Central Pacific to the Nazca Submarine Ridge in the southeastern Pacific (Gibson et al.,
2015). There have been reports of six marine fish species distributed along the Turkish coasts belonging to the Bothidae family: Arnoglossus imperialis (Rafinesque, 1810), Arnoglossus kessleri (Schmidt, 1915), Arnoglossus laterna (Walbaum, 1792), Arnoglossus rueppelii (Cocco, 1844), Arnoglossus thori (Kyle, 1913) and Bothus podas (Delaroche, 1809), but only three fish species belonging to this family: A. kessleri, $A$. laterna and $A$. thori have been reported from the Black Sea (Bilecenoğlu, Kaya, Cihangir, \& Çiçek, 2014).

According to FishBase (Froesa \& Pauly, 2019; https://www.fishbase.org) and the IUCN red list 
of threatened species (Golani, Kada, Nouar, Quignard \& Cuttelod, 2011; de Sola, Nielsen, Monroe, Costa \& Herrera, 2014); the scaldback, A. kessleri (Pleuronectiformes: Bothidae), is endemic to the Mediterranean and Black seas, and presents all through the Mediterranean Sea coast, except for Morocco and Algeria. It is found on the upper part of the continental shelf, and feeds on small fish and invertebrates. It is an uncommon species, but it is unknown if it is rare due to fishing activities. Therefore, $A$. kessleri is listed as a data deficient (DD) species in the IUCN red list of threatened species (Golani et al., 2011; de Sola et al., 2014).

The life history parameters, including only weight-length parameters (WLRs) and conditions for A. kessleri, were previously reported from different geographic regions, such as the Aegean Sea (Illkyaz, Metin, Soykan \& Kinacigil, 2008; Altın, Ayyıldız, Kale \& Alver, 2015; Bayhan, Sever \& Taşkavak, 2008; Türker-Çakır, Koç, Basusta, \& Basusta, 2008), the Marmara Sea (Ozen, Ayyildiz, Oztekin \& Altin, 2009; Türker-Çakır, Akalın, Ünlüoğlu, Bayhan \& Hoşsucu, 2003; Keskin \& Gaygusuz, 2010), the Mediterranean (Ergüden, Altun \& Ergüden, 2018) and also the Black Sea (Ak, Kutlu \& Aydin, 2009). Moreover, previous research for A. kessleri has been rather fragmentary in the Black Sea. Only one study has been conducted on the WLRs parameters in the Black Sea coast of Turkey so far (Ak et al., 2009). Furthermore, reproduction biology parameters such as spawning season, size at maturity and reproductive load, etc. are key population input parameters in the assessment and management of fish stocks (Tsikliras, Antonopoulou \& Stergiou, 2010; Tsikliras \& Stergiou, 2014). But, these reproduction biology parameters of $A$. kessleri have not previously reported from different geographic regions and also from the Black Sea. The objective of the present study was to contribute first information on the spawning period, to provide new findings on length at maximum yield per recruit $\left(L_{\text {opt }}\right)$ and reproductive load $\left(L_{m} / L_{\max }\right)$ of this species, and also to present a first estimation on the size at maturity $\left(L_{m}\right)$, necessary for the introduction of suitable management plans for $A$. kessleri in the Black Sea.

\section{MATERIALS AND METHODS}

\section{Study area and sampling}

Samples of the scaldback (A. kessleri) were collected using an experimental purposes beam trawl with $15 \mathrm{~mm}$ cod-end stretched mesh size up to $30 \mathrm{~m}$ water depths between December 2012 and November 2013 on the Rize province coasts of the southeastern Black Sea, Turkey (Fig. 1). Seasons were grouped as winter (December - February), spring (March - May), summer (June - August) and autumn (September - November). Although the beam trawl fishery is banned in the Rize province coasts of the southeastern Black Sea during the year, sampling surveys were conducted with a special permit to determine crab population dynamics project samples. The total length $(T L)$ of $A$. kessleri was measured after blot drying with a piece of clean towel. All specimens were measured to the nearest $1 \mathrm{~mm}$, and weighed to the nearest $0.01 \mathrm{~g}$. Total wet weight $(W)$ and gonad weight $\left(W_{\mathrm{g}}\right)$ were recorded to the nearest $0.1 \mathrm{~g}$.

\section{Maturity and spawning period}

The sex and the stage of maturity were recorded by macroscopic and/or microscopic examination of the gonads. The developmental stages of the gonads were classified for $A$. kessleri, taking

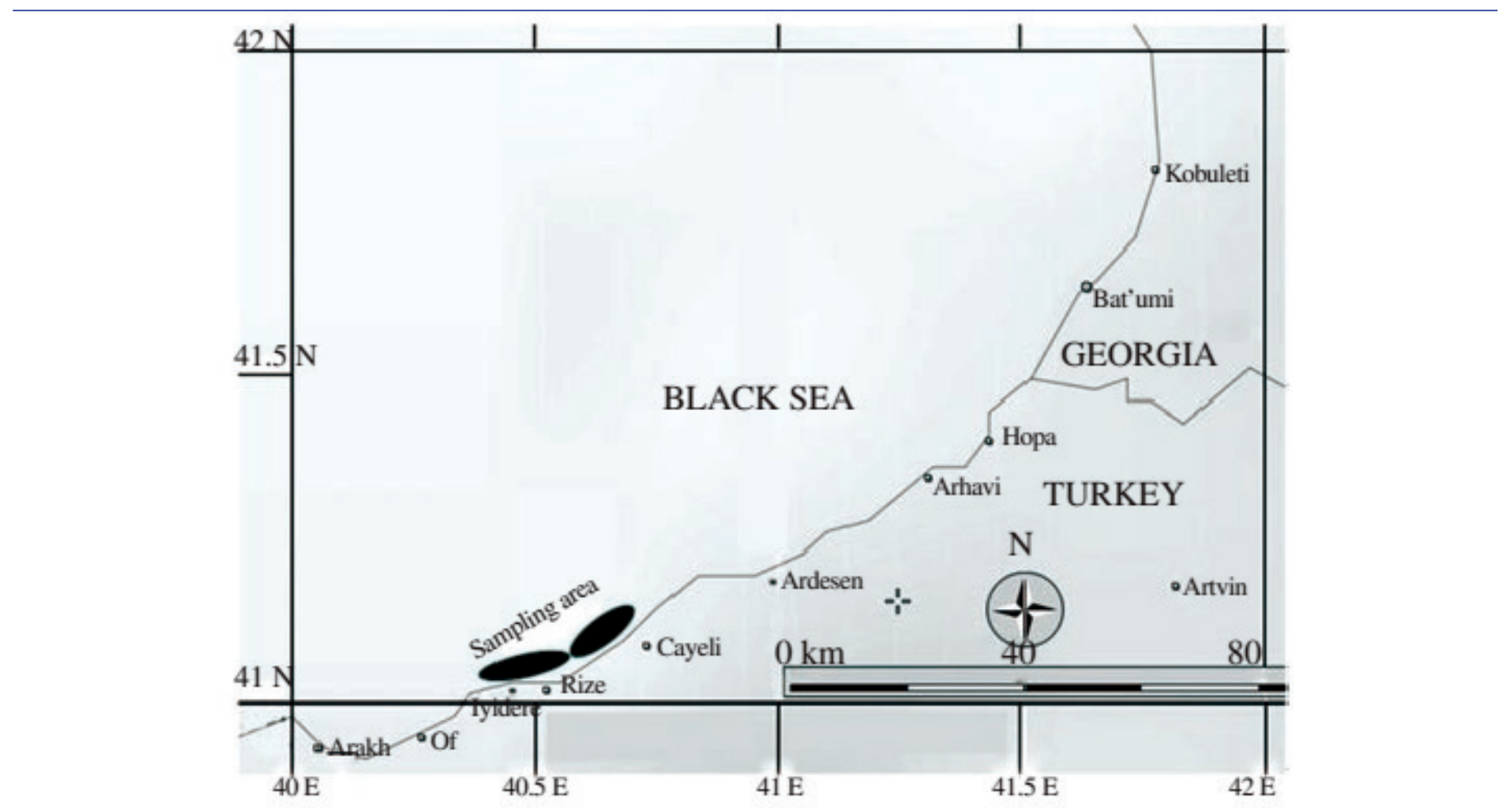

Figure 1. Beam trawl fishing operations sampling area on the Rize coasts in the southeastern Black Sea, Turkey. 
into account the criteria proposed for Actinopterygii species by Holden \& Raitt (1975) and for the greenback flounder, Rhombosolea tapirina by Barnett (1998). So, the maturity stages of the examined gonads were determined within four categories, based on the stages of the morphological characteristics: (stage I) immature virgin; (stage II) developing virgin and/or recovering; (stage III) ripe and/or spawner; (stage IV) resting or spent.

The spawning period was graphically determined for both sexes by the monthly variation of the mean values of the gonadosomatic index (GSI) as:

$\mathrm{GSI}=\frac{W g}{W}=100$

where, $W_{g}$ is gonad weight $(g), W$ is total scaldback weight $(g)$.

\section{Size at sexual maturity $\left(L_{m}\right)$}

Size at sexual maturity (defined here as the length at which 50\% of a population become sexually mature for the first time, $L_{m}$ ) was determined for females and males by calculating the proportion of mature females and males in the $0.5 \mathrm{~cm}$ size classes in the spawning period. Individuals with stage 2 and 3 in the gonad development stage were considered to be mature (Holden \& Raitt, 1975). The proportion of mature females and males by size were fitted to the logistic equation:

$P=\frac{1}{1+e^{a+b L}}$

where, $P$ is the proportion of mature females or males, $a$ and $b$ are the coefficients of the equation, and $L$ is the total length. Size at sexual maturity $\left(L_{m}\right)$, corresponding to $50 \%$ sexually mature for females and males, was calculated from - $(a / b)$.

\section{Length at maximum yield per recruit $\left(L_{\text {opp }}\right)$}

Froese and Binohlan (2000) suggested that if an estimate of length at first maturity is available, the length at maximum yield per recruit, $L_{\text {opt }}$ can be estimated. So, the $L_{\text {opt }}$ for both sexes of scaldback was calculated from the following empirical equation suggested by Froese \& Binohlan (2000).

$\log L_{\text {opt }}=1.053 \times \log \left(L_{m}\right)-0.0565$,

where, $L_{m}$ is the size at sexual maturity (or the length at which $50 \%$ of a population become sexually mature for the first time) of scaldback.

\section{Reproductive load $\left(L_{m} / L_{\max }\right)$}

$L_{m} / L_{\text {max }}$ ratio can be used to compare potential trends in maturation and energetic investment in reproduction, and/or growth for fish species (Tsikliras \& Stergious, 2014), and the ratio also expresses the proportion of the potential growth span of the species that is covered before maturation (Beverton, 1963), so the $L_{m} / L_{\max }$ ratio (\%) was calculated to express the reproductive load for both males and females of the scaldback.

\section{RESULT AND DISCUSSION}

A total of 1548 A. kessleri individuals were sampled during the study period, and it was determined that $44.1 \%$ of the samples were female $(n=682)$ and $55.9 \%$ male $(n=866)$. The sex ratio ( $f e-$ male/male) was calculated as 0.79 and the $\chi^{2}$ analysis showed that there was a statistically significant difference between the number of males and females $\left(\chi^{2}, P<0.05\right)$.

\section{Spawning period}

A total of 1548 scaldback (682 females and 866 males) were sampled during the study. But only a total of 878 scaldback gonads (483 female and 395 male) were examined and used for gonadosomatic index (GSI) estimation. Looking at the monthly changes in the GSI values variation (Fig. 2), the peak of the GSI values was clearly exhibited in June 2013 and then, the GSI values decreased until August 2013, and reached the lowest level in September 2013 for both female and male. This monthly fluctuation

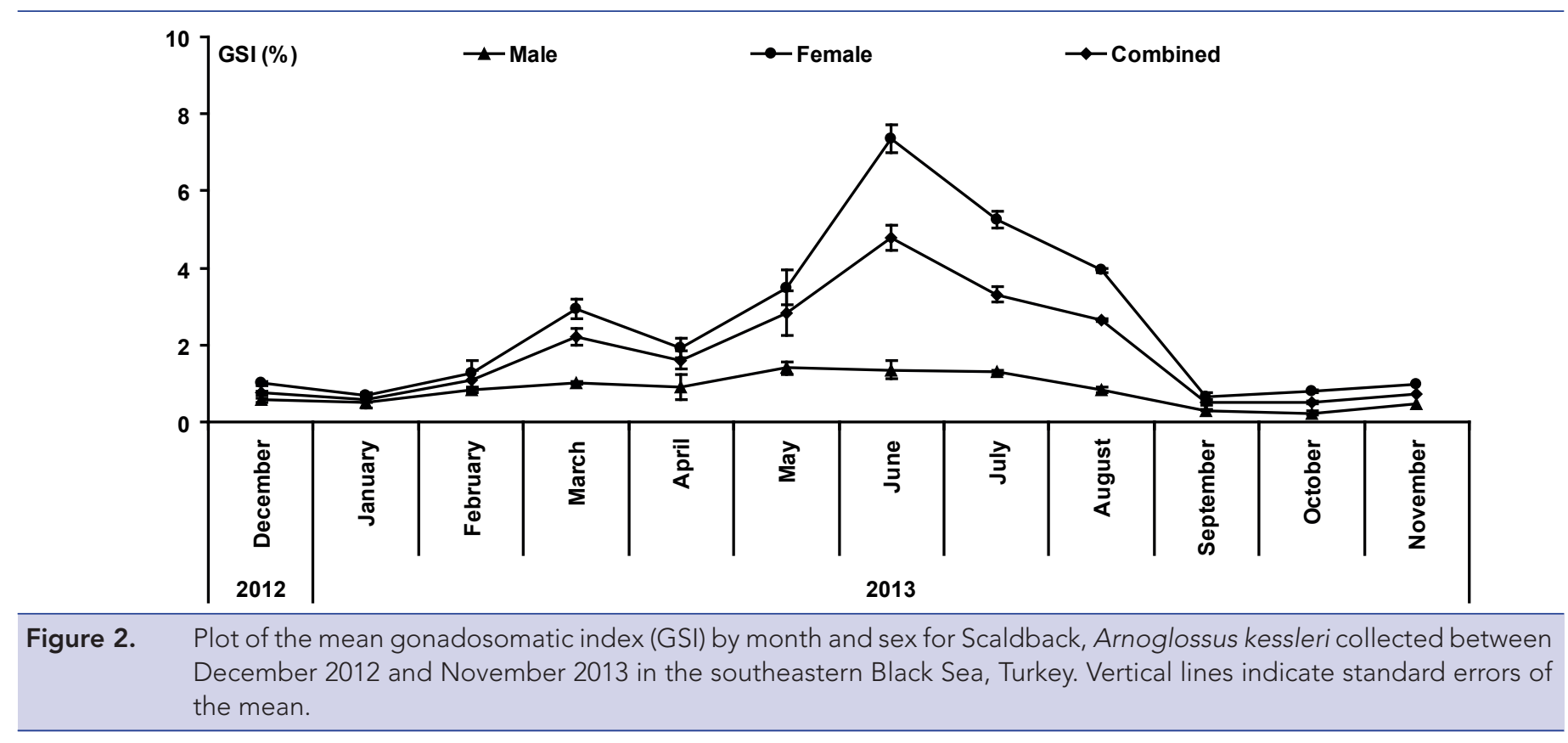


of the GSI values showed that the spawning period of scaldback was between June and September in the study area.

Spawning season, size at maturity and reproductive load of $A$. kessleri have not previously reported from different geographic regions and neither from the Black Sea. So, this study provides the first information on the spawning season and first maturity length. Based on the monthly fluctuation of the GSI values, the reproduction of $A$. kessleri was between June and September in the Black Sea. Similarly, the breeding period of $A$. kessleri was reported as between May and August by FishBase (Froese \& Pauly, 2019), based on Nielsen's (1986) report. But, this information is not based on field study. On the one hand, the spawning period of other Mediterranean scaldfish, A. laterna was reported from late June to August in the west coast of Scotland (northeast Atlantic) (Gibson \& Ezzi, 1980). Furthermore, the spawnin period of A. laterna was reported as throughout almost the year, but with the maximum spawning in August, and continuing until October in the east-central Aegean Sea, in Turkey by Ilkyaz, Metin, Soykan \& Kinacigil (2017), and from February to June in the Yumurtalık Bight, in Turkey (western Mediterranean) by Özütok \& Avşar (2004). Our findings also show reproduction in the similar time periods indicated by some of the previous studies. Although there is evidence that the duration of the spawning period may vary both annually and geographically, it was suggested that length of daylight is the main factor controlling the ovarian cycle, and that temperature controls the rate of egg laying (Holden, 1975). Moreover, all the studies' findings indicate a different time interval for the spawning period of Arnoglossus sp, and these results show that the spawning period has a close relation to the ecological characteristics of the water system in which the Arnoglossus species lives (ilkyaz et al., 2017).

\section{Length at maximum yield per recruit $\left(L_{\text {opt }}\right)$}

The $L_{\text {opt }}$ was estimated from the empirical relationships between length at maximum yield per recruit and size at maturity. Thus, $L_{\text {opt }}$ was calculated as $5.55 \mathrm{~cm}$ for females and $5.82 \mathrm{~cm}$ for males, and also, $L_{\text {opt }}$ was determined as smaller than $L_{m}$ for both sexes of scaldback.

The $L_{\text {opt }}$ is an important fisheries management parameter, because it can be a useful tool in defining routine fisheries management measures, such as MLS, closed seasons, etc. (Holt, 1958; Gulland, 1983; Frose \& Binohland, 2000). But, estimation of $L_{\text {opt }}$ requires knowledge of basic population parameters such as natural mortality $(M)$ and the von Bertalanffy growth function parameter, $K$. Those two parameters are not easily obtained. Therefore, an empirical relationship $\left(\log L_{\text {opt }}=1.053^{\star} \log L_{m}-0.0565\right)$ was reported between $L_{\text {opt }}$ and $L_{m}$ to provide an estimation of this parameter (Frose \& Binohland, 2000). To calculate $L_{\text {opt }}$ values for $A$. kessleri, we used Frose \& Binohland's (2000) empirical equation and $L_{\text {opt }}$, calculated as $5.6 \mathrm{~cm}$ for females and $5.8 \mathrm{~cm}$ for males. $L_{\text {opt }}$ values for females $(5.6 \mathrm{~cm}$ ) was smaller than for males (5.8), and $L_{\text {opt }}$ values $<L_{m}$ values for both sexes (male $L_{m}=6.0 \mathrm{~cm}$, female $L_{m}=5.8 \mathrm{~cm}$ ) of $A$. kessleri. It was reported that when using the recommended empirical formula for the calculation of $L_{\text {opt }}$ from $L_{m}$ there are differences between short-lived small fish and long-lived large fish species. Namely, if $L_{\text {opt }}$ estimates from $L_{m^{\prime}}$ the $L_{\text {opt }}$ value is generally smaller than at lower $L_{m}$ values, and it is generally longer than at higher $L_{m}$ values. E.g. for small $L_{m}$ values (e.g. $\left.L_{m}=10.5 \mathrm{~cm}\right), L_{\text {opt }}$ is calculated at a lower $(10.4 \mathrm{~cm})$ than $L_{m}$ , and also for higher $L_{m}$ values (e.g. $\left.L_{m}=90 \mathrm{~cm}\right), L_{o p t}$ is calculated at a higher $(100.3 \mathrm{~cm})$ than $L_{m}$. Since the Arnoglossus species, such as $A$. laterna, is a short-lived small fish species (Özütok \& Avşar 2002; illkyaz et al., 2017), it may be considered normal that $L_{\text {opt }}$ values $<L_{m}$ values for both sexes of $A$. kessleri stock in the Black Sea.

\section{Reproductive load $\left(L_{m} / L_{\text {max }}\right)$}

The $L_{m} / L_{\max }$ ratio (\%) of the scaldback calculated as 74.4 for males and 75.8 for females, and also $L_{m} / L_{\text {max }}$ ratio of female was estimated as a bit (1.4\%) larger than male. The $L_{m} / L_{\max }$ ratio of different species, such as $A$. laterna and $A$. thori belonging to Bothidae family, ranged between 0.59 and 0.70 for females and between 0.59 and 0.65 for males in the Mediterranean and Aegean Sea, and also the $L_{m} / L_{\max }$ ratio of female was generally larger than male (Özütok \& Avşar 2004; ilkyaz et al., 2017). In the present study, similar results were found for both sexes of $A$. kessleri stocks in the Black Sea. The $L_{m} / L_{\max }$ ratio for fish species may vary within and between different species due to latitude variation, depending on water temperature and nutritional quality or availability of food, energy output, etc. (Abookire \& Macewicz, 2003; Trip et al., 2014; Tsikliras and Stergious, 2014).

\section{Size at maturity $\left(L_{m}\right)$}

Total length of mature females ranged between 4.6 and $7.6 \mathrm{~cm}$ (mean: $41.6 \pm 0.61 \mathrm{~cm} ; \mathrm{n}=166$ ) and between 4.9 and $7.1 \mathrm{~cm}$ (mean: $6.1 \pm 0.21 \mathrm{~cm} ; \mathrm{n}=84$ ) for males.

Size at sexual maturity for females and males is shown in Fig. 3. The relationship between total length and the proportion of mature males was:

$$
\begin{aligned}
& P=\frac{1}{1+e^{11.403-1.892^{*} T L}} \text { and for female it was } \\
& P=\frac{1}{1+e^{7.853-1.364^{*} T L}} \text {, from this, the estimated size for } 50 \% \text { sex- }
\end{aligned}
$$

ual maturity $\left(T L_{50}\right)$ was $6.03 \mathrm{~cm}$ for males and $5.76 \mathrm{~cm}$ for females (Fig. 3).

We found that the sexual maturity size for males $\left(L_{m}=6.03 \mathrm{~cm}\right)$ was longer than for females $\left(L_{m}=5.76 \mathrm{~cm}\right)$ in the Black Sea. These $L_{m}$ results for both sexes are the first reported values in the literature for $A$. kessleri. However, there are reported $L_{m}$ results for other species, such as A. laterna belonging to Arnoglossus genus. Namely, the $L_{m}$ values (total length) of A. laterna were reported as $11.9 \mathrm{~cm}$ for females and $11.4 \mathrm{~cm}$ for males in the east-central Aegean Sea, Turkey (illkyaz et al., 2017), as $6.6 \mathrm{~cm}$ for males and $6.7 \mathrm{~cm}$ females in the Yumurtalık Bight (western Mediterranean, Turkey) by Özütok \& Avşar (2004), as $6.8 \mathrm{~cm}$ for combined sex in the Adriatic Sea, Italy (Giovanardi \& Piccinetti, 1984), and as 6-7 cm (standard length) for combined sex in the west coast of Scotland (northeast Atlantic) (Gibson \& Ezzi, 1980). These differences between the studies conducted in different seas are most probably due to species difference, different length composition used to size at maturity calculation, different sampling methods, different environmental conditions such as 

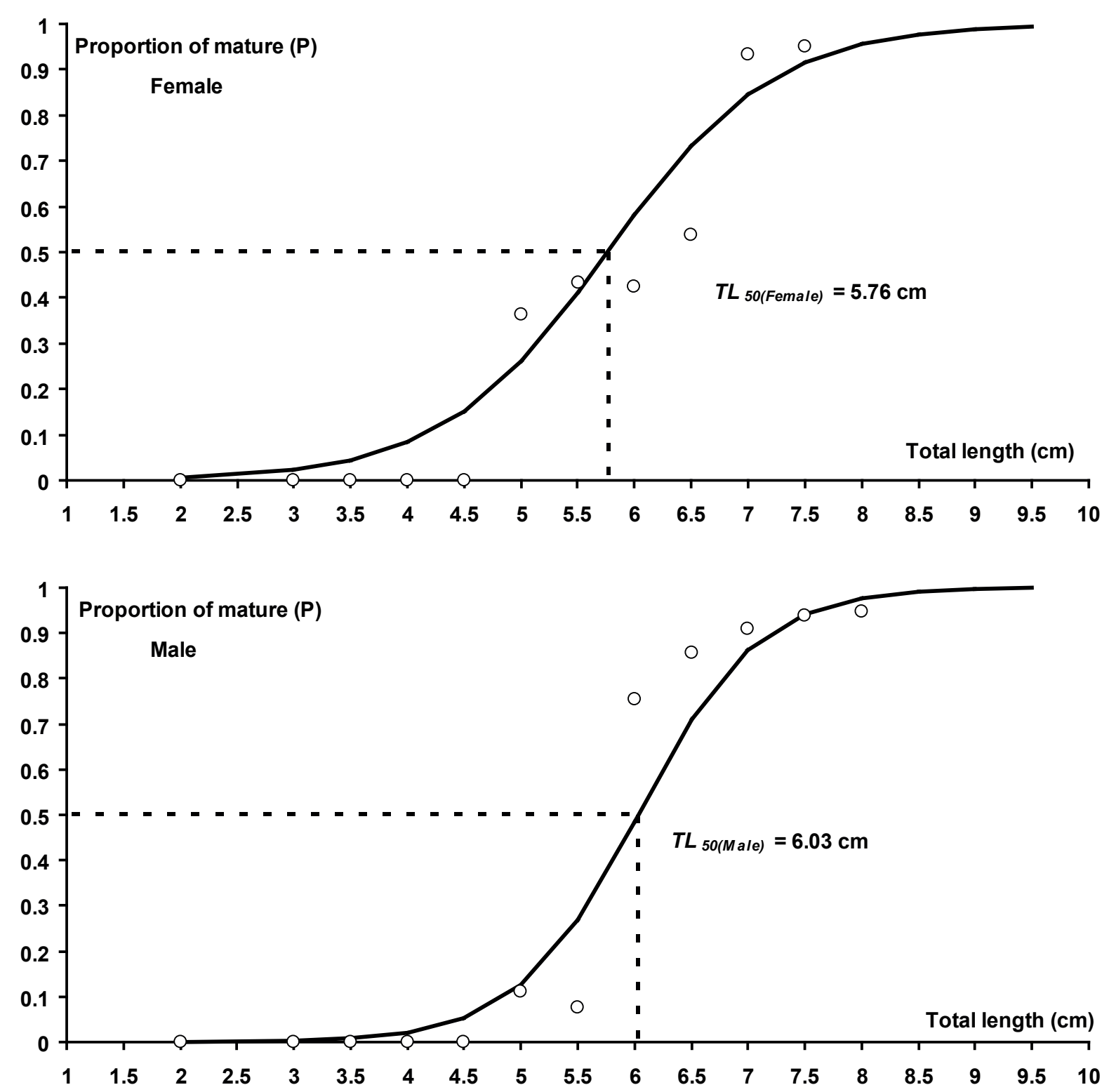

Figure 3. Plot of the size at sexual maturity by sex for Scaldback, Arnoglossus kessleri collected between December 2012 and November 2013 in the southeastern Black Sea, Turkey.

temperature, and different fishing pressure levels among the research areas and years, and also differences in the criteria for determining maturity. Furthermore, this variability may be due to environmental differences such as phenotypic variability (Tsikliras \& Stergiou, 2014), differences of biotic and abiotic factors such as temperature, salinity, competition, etc. Size at maturity is an important fisheries management parameter, because it is the basis for setting the minimum landing size (MLS) of fish stocks, i.e. the MLS under which fish should not be caught (Tsikliras \& Stergiou, 2014). Moreover, in the Black Sea (eastern Black Sea of Turkey), A. kessleri are not caught as a target fish species by fishermen, and also it is not amongst commercially important fish species, so no MLS limits are defined for the catch in the Black Sea and also other areas. The results of the present study could be used as bio- logical input parameters regarded as a reference (e.g., the MLS: $6 \mathrm{~cm}$ total length) for the management of the Black Sea stocks of this species.

\section{CONCLUSION}

The presently reported study provides the first information on the spawning period and size at maturity for the scaldback, $A$. kessleri for the Black Sea. The results of this study were offered as biological input parameters regarded as a reference for the management of the Black Sea stocks of the scaldback species.

Conflicts of interest: The authors have no conflicts of interest to declare. 
Ethics committee approval: This study was conducted in accordance with ethics committee procedures of animal experiments.

Funding: This study was funded by Recep Tayyip Erdoğan University, Scientific Research Project Office with project number 2010.103.03.1

Acknowledgement: We thank to Ozay Köse, Burak Taşçı, Yusuf Ceylan and Ahmet Kalkavan for their help in the field work.

\section{REFERENCES}

Abookire, A.A. \& Macewicz, B.J. (2003). Latitudinal variation in reproductive biology and growth of female Dover sole (Microstomus pacificus) in the North Pacific, with emphasis on the Gulf of Alaska stock. Journal of Sea Research, 50, 187-197. [CrossRef]

Ak, O., Kutlu, S. \& Aydin, I. (2009). Length-weight relationship for 16 fish species from the eastern Black Sea, Türkiye. Turkish Journal of Fisheries and Aquatic Sciences, 9, 25-126.

Altın, A., Ayyıldız, H., Kale, S. \& Alver, C. (2015). Length-weight relationships of forty-nine fish species from shallow waters of Gökçeada Island, northern Aegean Sea. Turkish Journal of Zoology, 39, 971-975. [CrossRef]

Barnett, C.W. (1998). Reproductive biology and endocrinology of the greenback flounder Rhombosolea tapirina (Günther, 1862). PhD. Thesis, University of Tasmania at Launceston, pp. 214. [CrossRef]

Bayhan, B., Sever, T.M. \& Taşkavak, E. (2008). Length-weight relationships of seven flatfishes (Pisces: Pleuronectiformes) from Aegean Sea. Turkish Journal of Fisheries and Aquatic Sciences, 8, 377-379.

Beverton, R.J.H. (1963). Maturation, growth and mortality of clupeid and engraulid stocks in relation to fishing. Rapp PV Réun Cons Int Explor Mer, 154, 44-67.

Bilecenoğlu, M., Kaya, M., Cihangir, B. \& Çiçek, E. (2014). An updated checklist of the marine fishes of Turkey. Turkish Journal of Zoology, 38, 901-929. [CrossRef]

de Sola, L., Nielsen, J., Monroe, T., Costa, M. \& Herrera, J. (2014). Arnoglossus kessleri (errata version published in 2016). The IUCN Red List of Threatened Species 2014:e.T194897A103945339.http:// dx.doi.org/10.2305/IUCN.UK.2014-3.RLTS.T194897A49088611.en. (accessed 23.07.2019) [CrossRef]

Ergüden, S.A., Altun, A. \& Ergüden, D. (2018). Length-weight relationship and condition of Arnoglossus kessleri Schmidt, 1915 in Iskenderun Bay (Eastern Mediterranean, Turkey). Sakarya University Journal of Science, 22, 1617-1622. [CrossRef]

Froese, R. \& Pauly, D. (2019). FishBase. World Wide Web electronic publication. www.fishbase.org, version (02/2019). (accessed 27.07.2019)

Frose, R. \& Binohlan, C. (2000). Emprical relationships to estimate asymptotic length, length at first maturity and length at maximum yield per recruit in fishes, with a simple method to evaluate length frequency data. Journal of Fish Biology, 56, 758 - 773. [CrossRef]

Gibson, R.N. \& Ezzi, I.A. (1980). The biology of the scaldfsh, Arnoglossus laterna (Walbaum) on the west coast of Scotland. Journal of Fish Biology, 17(5), 565 - 575. [CrossRef]

Gibson, R.N., Nash, R.D.M., Geffen, A.J. \& van der Veer, H.W. (2015). Flatfishes: biology and exploitation. Fish and Aquatic Resources Series: Wiley Blackwell. ISBN 1118501195,9781118501191 [CrossRef]
Giovanardi, O. \& Piccinetti, C. (1984). Biology and fishery aspects of the scaldfish Arnoglossus laterna (Walbaum, 1792), in the Adriatic Sea. In: Technical Consultation on Stock Assessment in the Adriatic 3, Fano, Italy, 6 June 1983, FAO Fisheries Report no 290, Fishery Policy and Planning Division, (pp. 161-166) FAO, Rome.

Golani, D., Kada, O., Nouar, A., Quignard, J.P. \& Cuttelod, A. (2011). Arnoglossus kessleri. The IUCN Red List of Threatened Species 2011 e.T194897A8917203. (accessed 20.07.2019)

Gulland, J.A. (1983). Fish stock assessment. A manual of basic method. FAO, Wiley Series on Food and Agriculture: Rome. ISBN-10: 0471900273

Holden, M.J. (1975). The fecundity of Raja clavata in British waters. ICES Journal of Marine Science, 36, 110 - 118. [CrossRef]

Holden, M.J. \& Raitt, D.F.S. (1975). Manual de ciencia pesquera. Parte 2. Método para investigar los recursos y su aplicación. FAO Doc. Tec. Pesca $115 \mathrm{p}$.

Holt, S.J. (1958). The evaluation of fisheries resources by the dynamic analysis of stocks, and notes on the time factors involved. ICNAF Special Publication, 1, 77 - 95

Illkyaz, A.T., Metin, G., Soykan, O. \& Kinacigil, H. (2008). Length-weight relationship of 62 fish species from the Central Aegean Sea, Turkey. Journal of Applied Ichthyology, 24, 699-702. [CrossRef]

Illkyaz, A.T., Metin G., Soykan, O. \& Kinacigil H.T. 2017. Age, growth, and reproduction of Mediterranean scaldfish, Arnoglossus laterna (Actinopterygii: Pleuronectiformes: Bothidae), in the east-central Aegean Sea. Acta Ichthyologica et Piscatoria, 47: 53 - 61. [CrossRef]

Keskin, C. \& Gaygusuz, Ö. (2010). Lengthweight relationships of fishes in shallow waters of Erdek Bay (Sea of Marmara, Turkey). IUFS Journal of Biology, 69, 87-94.

Nielsen, J.G. (1986). Bothidae. In P.J.P. Whitehead, M.-L. Bauchot, J.-C. Hureau, J. Nielsen and E. Tortonese (Eds.), Fishes of the Northeastern Atlantic and the Mediterranean (p. 1294-1298). [CrossRef]

Ozen, O., Ayyildiz, H., Oztekin, A. \& Altin, A. (2009). Length-weight relationships of 17 less-studied fish species from Çanakkale, Marmara region of Turkey. Journal of Applied Ichthyology, 25, 238-239. [CrossRef]

Özütok, M. \& Avşar, D. (2004). Reproduction of the scaldfsh (Arnoglossus laterna Walbaum, 1792) from the Yumurtalık Bight (Adana). E.U. Journal of Fisheries and Aquatic Sciences, 21(1-2), 1-4.

Trip E.D.L., Clements, K.D., Raubenheimer, D \& Choat, J.H. (2014). Temperature-related variation in growth rate, size, maturation and life span in a marine herbivorous fish over a latitudinal gradient. Journal of Animal Ecology, 83, 866-875. [CrossRef]

Tsikliras, A.C. \& Stergiou, K.I. (2014). Size at maturity of Mediterranean marine fishes. Reviews in Fish Biology and Fisheries, 24, 219-268. [CrossRef]

Tsikliras, A.C., Antonopoulou, E \& Stergiou, K.I. (2010). Spawning period of Mediterranean marine fishes. Reviews in Fish Biology and Fisheries, 20, 499-538. [CrossRef]

Türker-Çakır, D., Koç, H.T., Basusta, A. \& Basusta, N. (2008). Lengthweigth relationships of 24 species from Edremit Bay, Aegean Sea. e-Journal of New World Sciences Academy, 3, 47-51.

Türker-Çakır, D., Akalın, S., Ünlüoğlu, A., Bayhan, B. \& Hoşsucu, B. (2003). The flatfish species in Edremit Bay and length-weight relationships for three of them Citharus linguatula (Linnaeus, 1758), Arnoglossus laterna (Walbaum, 1792), Arnoglossus kessleri (Schmidt, 1915). Ege University Journal of Fisheries and Aquatic Sciences, 20, 529-536. 